\title{
Dante, Television, and Education
}

\section{Introduction}

The entry on television in the Enciclopedia dantesca, written in the early 1970's, notes that Dante has not been well-served by the medium. The relatively few arid attempts to televise him have met with limited success (Antonucci). This is surprising, since the textual characteristics of Dante's Divine Comedy are in many ways similar to those of television. But perhaps this was not as evident then as it is now. (And even now it is probably not evident to everyone.) Whatever the case, this belated realization may, in part, explain the recent interest in "translating" Dante from print into video.

In the past few years there have been three such efforts. A onehundred part series on the Divine Comedy, produced by the Dipartimento Scuola Educazione of RAI TV, was shown in 1988 on prime time. The other two are in various stages of elaboration. Channel Four Television in Britain has a thirty-four part series on the $I_{n-}$ ferno in production. So far only the pilot on Inferno 5 is complete (1985). Finally, the Media Centre at the University of Toronto has produced two half-hour programmes in its Dante's Divine Comedy: A Televisual Commentary. They are "Dante's Ulysses and the Homeric Tradition" (1985) and "Vulcan's Net: Passion and Punishment" (1987). A third programme on "Dante's Universe" is under way, and more are planned. I am involved in the latter enterprise.

Of the three projects, the RAI and the University of Toronto productions are explicitly educational in intention, although the RAI venture also aspires to "avvicinare un largo pubblico a La Divina Commedia."2 On the other hand, the University of Toronto initiative is not even intended for broadcast: it is designed for the classroom and is directed specifically at North American undergraduate students who are coming to the poem for the first time. By far the most ambitious in scope is the British $A T V$ Dante, which carries the signature of a talented avant-garde director, Peter Greenaway. 
Tom Phillips, the well-known painter and recent translator and illustrator of the Inferno, shares the direction of the pilot programme with Greenaway. ${ }^{3}$ In it they attempt, among other things, to translate Dante's plurilinguism (Contini) into the language of television, and, to a great extent, succeed. Their aim is obviously not didactic, not in the institutional sense at any rate, but this programme too could, if properly introduced and contextualized, be used effectively in the classroom.

Is this legitimate? Is it appropriate to use television to teach a literary text? If it is, then why is it? How can television be used? In what way can it be integrated into an overall pedagogical strategy? I limit the following discussion to Dante's Divine Comedy and the three television projects mentioned above.

\section{Dante's Audience Then}

In his Life of Dante, Boccaccio recounts the following anecdote:

[Dante's] complexion was dark, and his hair and beard, thick, black, and crisp; and his countenance always sad and thoughtful. And thus it happened one day in Verona ... that, as he passed before a doorway where several women were sitting, one of them said to the others ... "Do you see the man who goes down into hell and returns when he pleases, and brings back news of those who are below?" To which one of the others naively answered, "Indeed, what you say must be true; don't you see how his beard is crisped and his colour darkened by the heat and smoke down there?" $(42-43)$

Even when Boccaccio puts on the robes of the biographer or commentator, he remains a teller of tales. The story is probably apocryphal, but it confirms what we know from other sources about the early diffusion of Dante's poem and the audiences to which it appealed. ${ }^{4}$

Dante's Comedy was, in its time, what today we would call an instant best seller. It penetrated all levels of contemporary society. The literate read it, transcribed it, and passed it on to friends-the manuscript tradition assures us of this. This group recognized the poem's greatness immediately and soon elevated it from the rank of a best seller to that of a classic, if one measure of a classic is the amount of critical literature it inspires. Dante had hardly settled into his grave before the first glosses appeared. His sources were tracked 
down and listed, and the literal and allegorical meanings of his poem were expounded. No verse was left unremarked. By the end of the fourteenth century, Dante's poem had generated more commentary than Virgil's Aeneid had throughout the whole of the Middle Ages. At the same time, those unable to read, like the women of Verona, gathered eagerly in public squares to hear the latest news from the other world. So powerful was their belief in the actual, physical existence of hell, and so persuasive were Dante's words in conjuring up that world, that they accepted fiction as fact.

The popularity of Dante's poem derives from its polysemous nature, which allows it to speak to audiences that are different socially and culturally, as well as historically, from the illiterate to the most educated and pedantic. Built into the poem's allegory are many possible readings, all of which flow naturally from the literal narrative. By this I do not mean to imply that the Comedy's polysemy is boundless and structureless. The text delineates the terrain within which meanings may be made. In terms of the text's intentionality, the women of Verona's decoding is not "aberrant," nor is their reading as "naive" as Boccaccio would suggest. ${ }^{6}$ They are highly competent decoders of oral modes of communication, if not sophisticated "readers." Within the context of an oral performance of the Comedy, they would bring to the poem a knowledge of the imagery with which it is constructed and an understanding of its textual conventions sufficient to make sense of it and derive pleasure from the experience. That is why-Boccaccio tells us-Dante was not displeased by their reaction. He realized that, by taking his words as literal truth, they had grasped the poem's ethical and didactic message, which is "to remove the living from a state of misery in this life and to guide them to a state of [eternal] happiness." Indeed, Dante had written his Comedy in Italian rather than Latin, and in a simple style rather than a complex one, "so that even women [i.e. the illiterate] would understand it" (Epistle 13).

\section{Dante and Oral Culture}

The Comedy's distinctive textual characteristics were in part derived from and inserted into a popular culture in which orality played an important role. And, indeed, the poem possesses many of the qualities, listed by Fiske and Hartley, typical of oral modes of com- 
munication: dramatic, episodic, mosaic, dynamic, active, concrete, social, metaphorical, rhetorical, dialectical. ${ }^{7}$ To these we must add its "memorability," the ease with which sections of it can be learnt by heart and recited aloud, as well as the sense of "nowness" it creates. The oral reception of the poem in segments engenders the feeling of an "unwritten" text, of a poem in fieri where the next episode has yet to happen. Moreover, the predominance of contemporary characters and situations enhances this impression of "nowness." Dante meets Francesca, not Iseult or Dido: Francesca-bourgeois, Italian, contemporary. A series of "distances"-social, spatial, and temporalare thus removed. The text seems unmediated; the experience is immediate. Think of the gossip this must have fuelled among the women of Verona and the speculation about whom Dante would encounter when next he descended into hell!

In saying this, I do not intend to diminish in any way the Comedy's status as a textual object. Dante's poem also possesses, in one way or another, all the formal characteristics of literate communication, ${ }^{8}$ which are in tension with those of the opposing oral mode. Moreover, in it Dante speaks as a scribe and a maker of texts and consistently addresses the reader, not the listener (Auerbach, Spitzer, Russo). The literary nature of the Comedy is so evident and has been so thoroughly studied that to dwell on it is almost superfluous. Unlike such anonymous poems as Beowulf, the Chanson de Roland, and the Cid, which grew out of primarily oral cultures (Zumthor), Dante's Comedy was the product of a self-conscious poet writing in a sophisticated urban society which boasted a significant reading public. However, it is equally true, as Ahern points out in "Singing the Book," that "the literate culture of the Italian communes contained a very high residue of orality" and that a majority of the population was either illiterate or only marginally literate (21). That Dante does not wish to exclude this group from enjoying his poem and profiting from it is confirmed not only by the passage cited above from the Letter to Cangrande but also by the linguistic texture of the poem itself. ${ }^{9}$ For instance, the fact that Dante wrote the poem in the vernacular, in a relatively simple style, in a frequently sung meter, and in easily performable units of approximately 140 verses, argues that he wanted to reach a wide audience, including even the illiterate.

For Dante, the women of Verona's oral reception of the poem and 
response to it may be incomplete but not inappropriate nor invalid. A more complete response would involve a twofold reception (cither simultaneous or consecutive) by the literate, in which the poem's aural reality would be experienced along with a slow, reflexive reading of the text. Dante's listening public, or at least a large, intelligent group within it, soon realized that it did not possess the necessary competence to give the poem the full response it demanded. Perhaps this explains why in 1373 a group of semi-literate persons (referred to as "non gramatici" in the extant document) petitioned the Florentine authorities for a public reading of and commentary on the Divine Comedy. ${ }^{10}$ So began the lectura Dantis tradition, inaugurated by Boccaccio himself. But from the outset the form became a literate vehicle for academic closure: learned words engulfed the Comedy's many voices. ${ }^{11}$ It is this commentary tradition, reinforced by Gutenberg, which has prevailed. But the poem owes its continuing popularity not so much to the lectura Dantis tradition as to the ease with which it can be inserted into oral culture, from which it originally sprang. Moreover, it could be argued that a part of its meaning can best be grasped through oral performance rather than through silent, solitary reading.

Walter Ong, citing Havelock, distinguishes the production of meaning and pleasure in oral culture as opposed to literate culture:

... for an oral culture, learning or knowing means achieving close, empathetic, communal identification with the known (Havelock 1963, pp. 14546) ... Writing separates the knower from the known and thus sets up conditions for "objectivity," in the sense of personal disengagement or distancing. (45-46)

The fact that Dante's poem possesses characteristics of both oral and literate modes of communication allows it to elicit both responses, depending on how it is received and the cultural preparation of the group receiving it. In other words, the Divine Comedy opens itself up equally to the immediate, empathetic response of the women of Verona and the more objective, disengaged response of the individual reader. In the first case, the aural impact of Dante's verbal imagery collapses the distinction between the fictional world being described and reality, and establishes a close relationship between the audience and the thing evoked. Here, meaning is produced through identification with and participation in the action of the poem and is grasped 
without reflection. Even the moral significance at the heart of Dante's purpose is communicated immediately, since it flows naturally from the literal images, which are part of the known, i.e. part of the cultural consciousness and memory of even the women of Verona. However, in the struggle for meaning (and how this meaning is to be produced and transmitted), the women of Verona's immediate literal "reading" lost out to the more abstract, stratified, allegorical discourse of the literate. In the process, the aural/oral dimension of the poem and much of what Contini calls the Comedy's "altra polisemia," i.e. the allusive density of the literal level, ${ }^{12}$ have been lost.

\section{Dante's Audience Today}

Dante's audience is as varied today as it was when the Divine Com$e d y$ first appeared, cutting across class divisions and national boundaries. Moreover, it continues to enjoy a large public, selling hundreds of thousands of copies a year worldwide. ${ }^{13}$ A significant portion of this public is made up of students who typically are required to read the poem in a heavily annotated edition, in other words, as a classic rather than as a best seller. Mediation is necessary, of course. Seven hundred years separate us from the world of Dante's poem. We are no longer in touch with its language, iconography, and cultural assumptions, with its political, theological, mythological, and literary allusions. How can this context, necessary for the production of meaning-meaning, to be precise, which is not aberrant-best be recreated? With an old text, the production of meaning must take into account and be respectful of both our and the text's differing historical situations.

In fine, what form should the mediation take, especially for North American undergraduate students reading the Divine Comedy for the first time? Is the lectura Dantis the most appropriate form? Another anecdote, this one true! In the main undergraduate course on Dante at the University of Toronto a few years ago, the Sapegno edition of the Comedy was prescribed. However, we quickly discovered that the students were having more difficulty negotiating Sapegno's learned notes than deciphering Dante's naked verses. The following year we adopted Grandgent's less encumbering edition. The issue is not, of course, the quality of Sapegno's gloss. Despite its age-the first edition appeared in 1955-it remains one of the most sophisticated 
and intelligent commentaries on the market. Rather it is the linguistic and cultural preparation of our students, as well as which strategy to use as a first approach to the poem. ${ }^{14}$

\section{Dante, Television, and Education}

Perhaps a pedagogical strategy which is more sensitive to our students' historical and geographical situation and that of the text, for that matter, is in order. Let us start with the text. The Comedy is neither an open nor a closed text (Eco, The Role of the Reader); it is neither writerly nor readerly (Barthes). An open or writerly text, at least as Eco and Barthes originally theorized it, is multiple, difficult, and self-reflexive, designed for the refined reader who delights in discovering its complex discursive strategies and consequently in participating in a writerly way in the production of meaning. On the other hand, a closed or readerly text is one which "reads" easily and thus has wide popular appeal. It seems to function at one level only - that of reality - and uses standard signifying practices to convey this impression. Although the Comedy' exhibits many of the qualities of an open or writerly text, it also "reads" easily and succeeds in communicating meaning and giving pleasure even to those unable to appreciate the nature of its elaborate allegorical discourse. Because of this, Dante's Comedy is more like what Fiske calls, with specific reference to television, a "producerly text." "A producerly text," Fiske states, adapting Barthes' terminology, "combines the televisual characteristics of a writerly text with the easy accessibility of the readerly" (95). The problem, of course, is that the "readerly" aspect of Dante's text has become less accessible, for the reasons listed above. Moreover, the text is presented to students in a quintessentially literate and academic form-the lectura Dantis. This format disregards, to a great extent, both the nature of the text's polysemy and the "reading" competence of a large part of Dante's audience, both then and now.

Most undergraduate students today, like the women of Verona, are highly competent decoders of oral modes of communication. Indeed, they are perhaps more television-literate than book-literate, and able, therefore, if pointed in the right direction, to retrieve in part the aural/oral dimension (largely lost) of Dante's poem, something that simply reading the poem aloud can no longer hope to do. As 
McLuhan and others since him (Ong, Schwartz, Fiske, etc.) have shown, television is primarily an auditory-based medium. ${ }^{15}$ Watching television, the eye functions like an ear, or, to put it in the more colourful language of a nine-year-old child in Hodge and Tripp's research project on children and television: "You sorta listen with your eyes" (41). Through television, it may be possible to recover not only some of the Divine Comedy's contents (its iconography, for instance), but also to re-experience, in part, at any rate, the mode in which the poem was received by a large segment of its original audience.

I keep saying "in part" because the orality produced by today's electronic society is essentially different from the traditional kind in that it is based on and derived from literacy. Walter Ong calls it "secondary orality":

With telephone, radio, television and various kinds of sound tape, electronic technology has brought us into the age of "secondary orality." This new orality has striking resemblances to the old in its participatory mystique, its fostering of a communal sense, its concentration on the present moment, and even its use of formulas. But it is essentially a more deliberate and self-conscious orality, based permanently on the use of writing and print, which are essential for the manufacture and operation of the equipment and for its use as well. (136)

Although I have stressed the similarities between the "reading" competence of the women of Verona and today's students, it is also important to note the differences, lest we abuse Dante, television, and our students. Although it may be true that, culturally and intellectually, the great majority of today's students are formed more by television than by books, they can read, and many even derive pleasure from the act. In the last analysis, therefore, they are closer to Dante's literate contemporaries than they are to the women of Verona: the possibility of a twofold reception of the poem is open to them. However, unlike the litterati of Dante's time, they are not hostile to the oral mode (in its new electronic form, of course). This places today's students in a unique position to apprehend and to appreciate the Comedy's complex polysemy, both the "altra polisemia" of the literal level and the more formal, structured polysemy of the extraliteral senses. The former, I believe, can best be grasped through the new orality of today's electronic media, television in particular. 


\section{Dante on Television}

So far I have concentrated my attention on how, through a deliberate and self-conscious use of television, it may be possible, in theory, to recreate in some measure an experience of the poem which promotes the production of those meanings contained in the text's allusive literal narrative. Whether or not this is achieved, however, depends on how effectively the medium is used. In Understanding Media, McLuhan noted that "merely to put the present classroom on TV would be like putting movies on TV. The result would be a hybrid that is neither" (289). I shall now turn to the three television projects mentioned earlier and briefly discuss each.

\section{The Lectura Dantis Televised}

Despite the big budget, the RAI production is unsatisfactory both as an educational tool and as a commercial venture. (One of the declared intentions of the undertaking, as I have already noted, was to make Dante accessible to as wide an audience as possible.) It is bookish television: in sum, little more than a lectura Dantis televised. Directed by Marco Parodi, each canto is introduced by Giorgio Petrocchi, the project's academic co-ordinator, and then read by a famous actor (Albertazzi, Sbraglia, Salerno). Finally, a commentary is provided in an artificially constructed dialogue between two established scholars (e.g. Baldelli, Borsellino, Pasquazi, Petrocchi, Tartaro, Vallone). The interpretative readings are too theatrical for the medium; the commentary is basic, but still too learned for the intended audience. Its presentation is both awkward and uninspired. Furthermore, the introduction and debate are set in the magnificent Biblioteca Vallicelliana in Rome, which accentuates the distinctly academic tone of the affair, and serves, of course, to distance its audience even further. The production is sensitive neither to the language of television nor to the telepotential language of Dante's Comedy. As a classroom aid, it can be used to impart information and little more: however, the information could be conveyed better through the more traditional pedagogical genre of the formal lecture, with a few slides thrown in. RAI has put the book on TV: the result is a hybrid that is neither. ${ }^{16}$ 


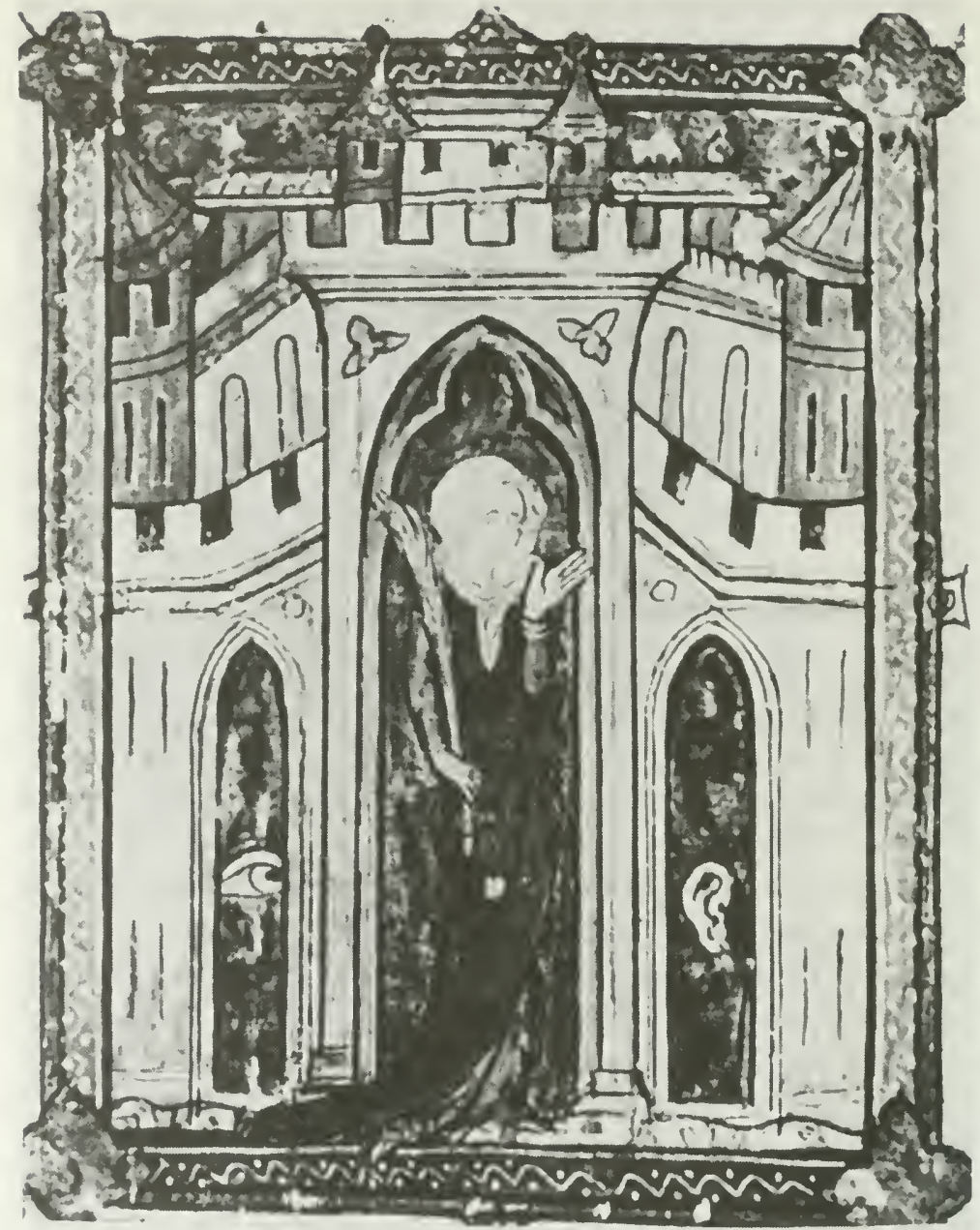

Fig. 1. The Castle of Memory in a manuscript of Li Bestiaires d'amours. Paris, Bibliothèque Nationale Ms. fr. 1951, f. 1 (French, early 14 th cent.). 


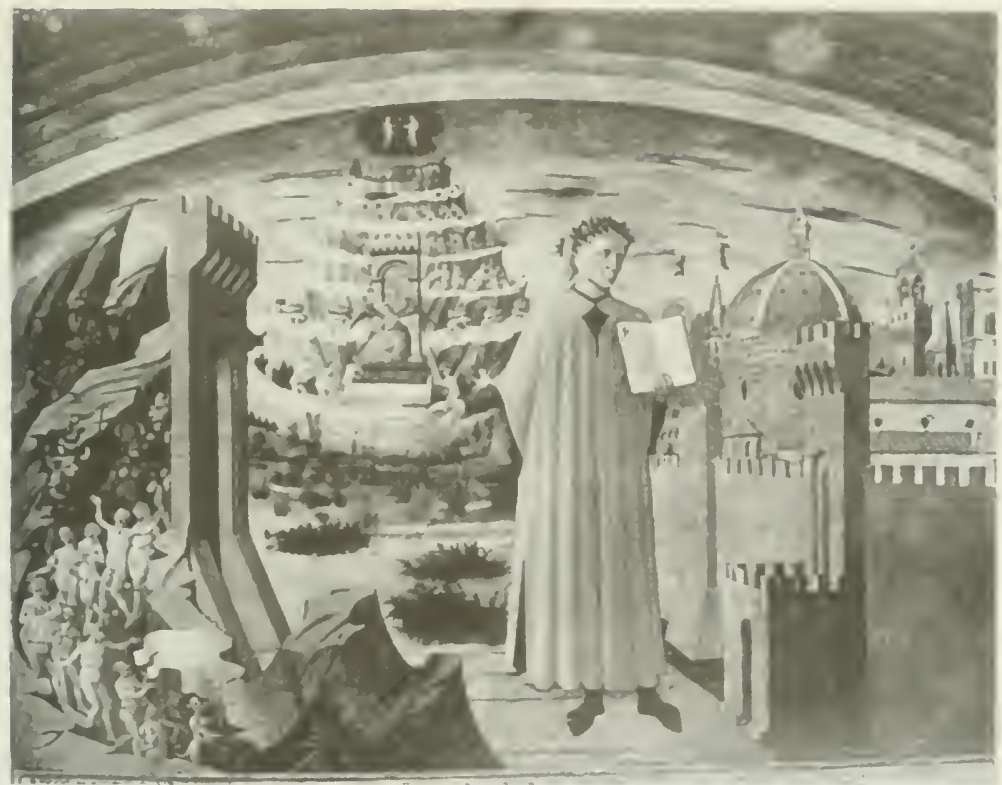

Fig. 2. Dante and his poem. Fresco by Domenico di Michelino in Santa Maria del Fiore, Florence (1465). 


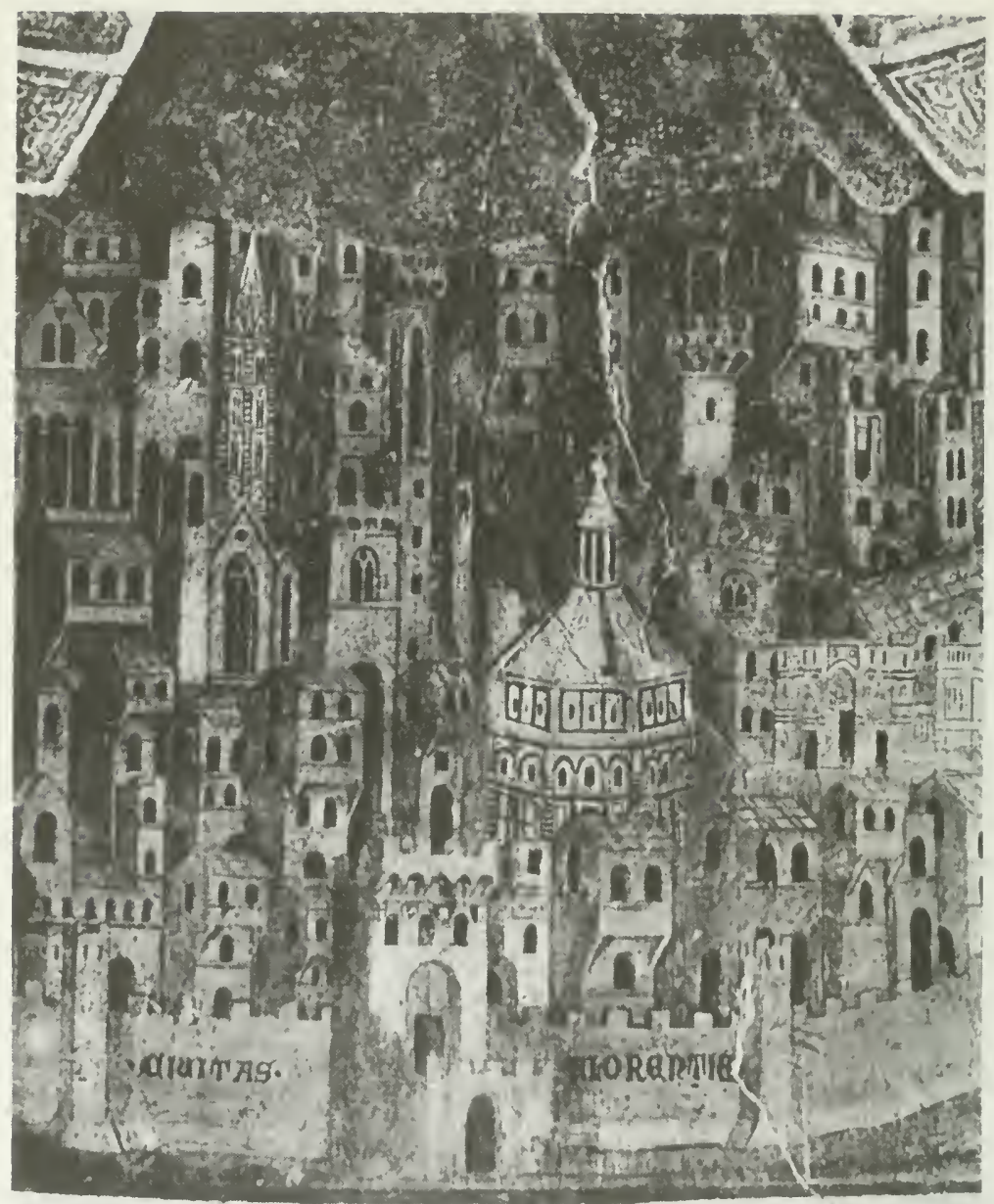

Fig. 3. View of Florence. Detail from the "Madonna della Misericordia" fresco in the Orfanotrofio del Bigallo, Florence (1352). 


\section{+ LVNA.}

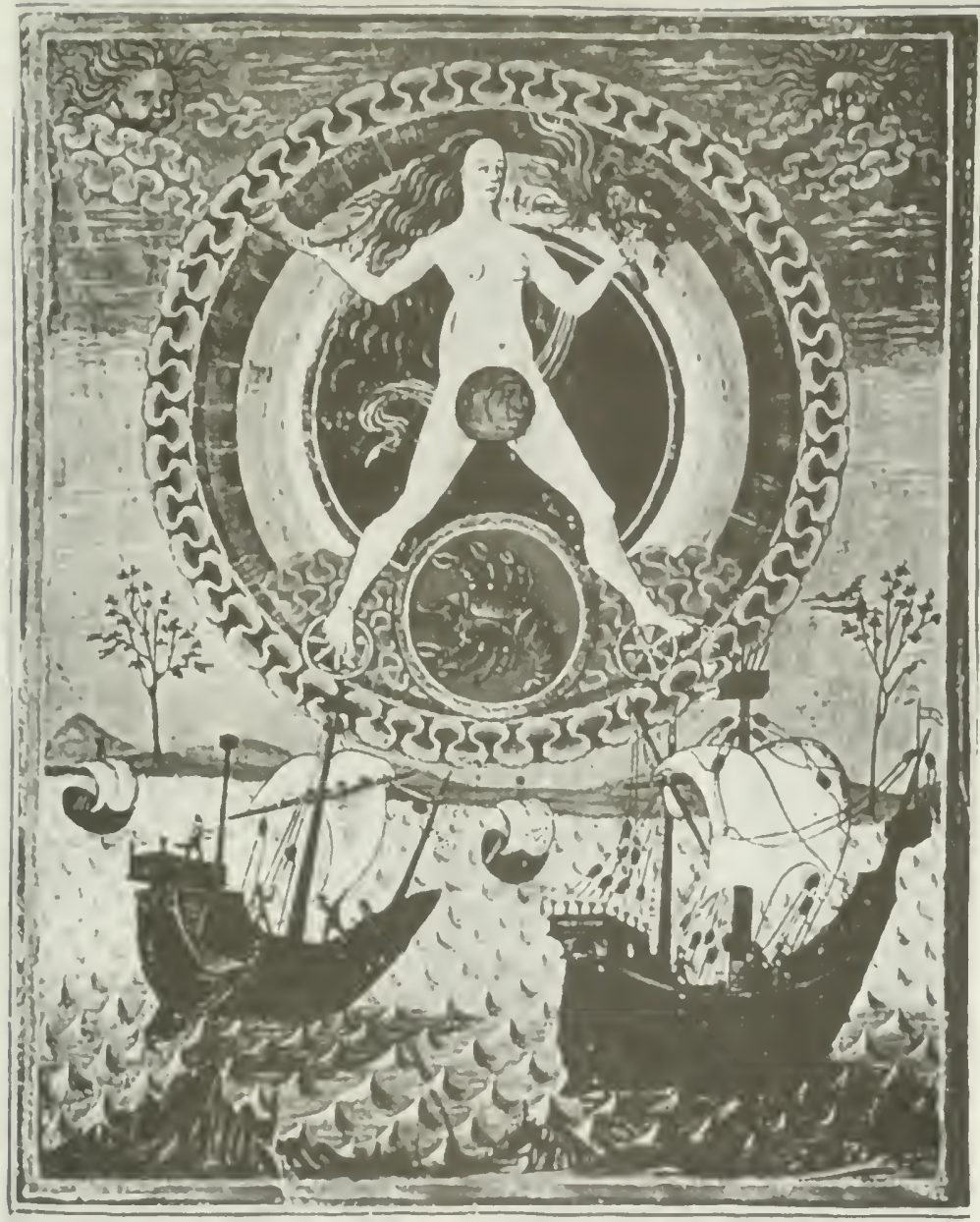

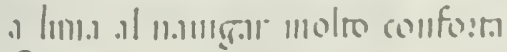

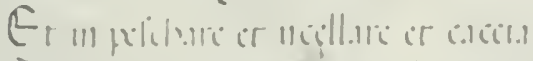

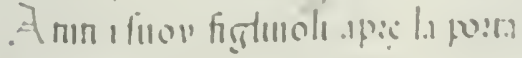

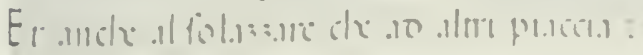

Fig. 4. Luna and her influence. De sphaera. Modena, Biblioteca Estense, Ms. lat. 209 (Italian, 15th cent.). 


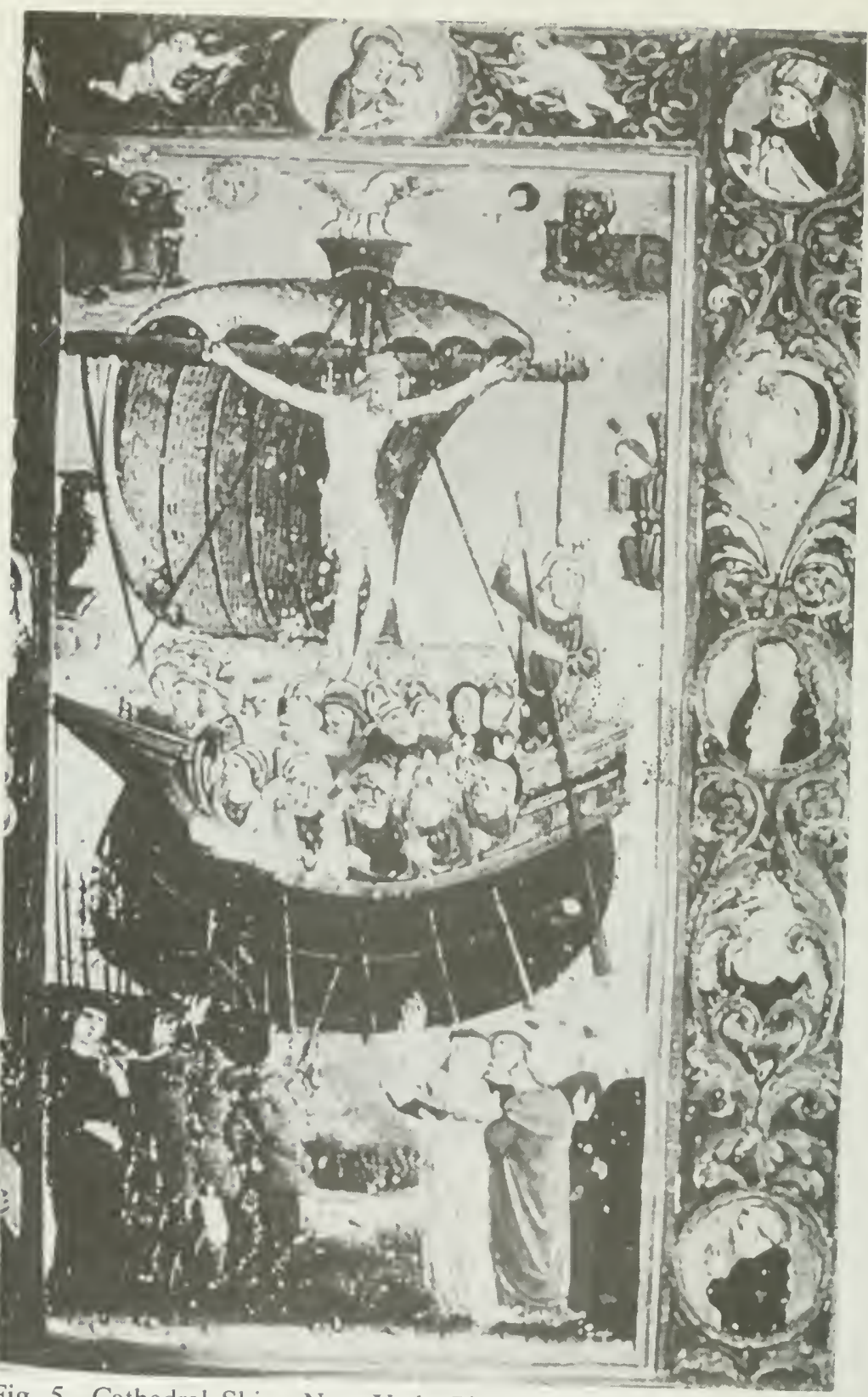

Fig. 5. Cathedral Ship. New York, Pierpont Morgan Ms. M. 799, f. $234 v$ (Italian, 15 th cent.). 


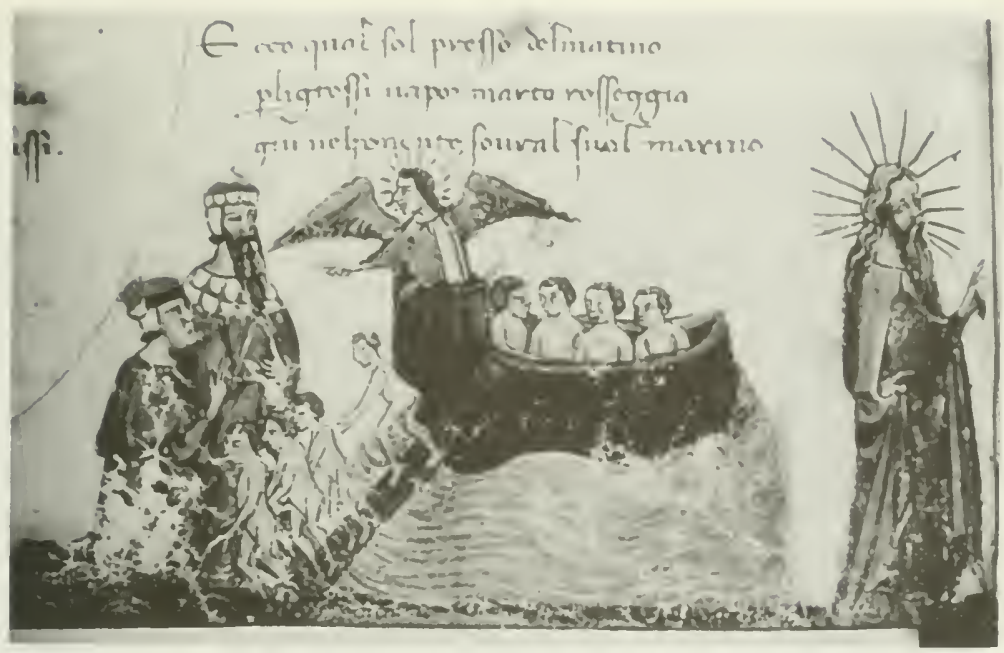

Fig. 6. Purgatorio 2. The ship of the souls. Florence, Biblioteca Laurenziana, Ms. Strozz. 152, f. 31v (Florentine, ca. 1335-1345). 


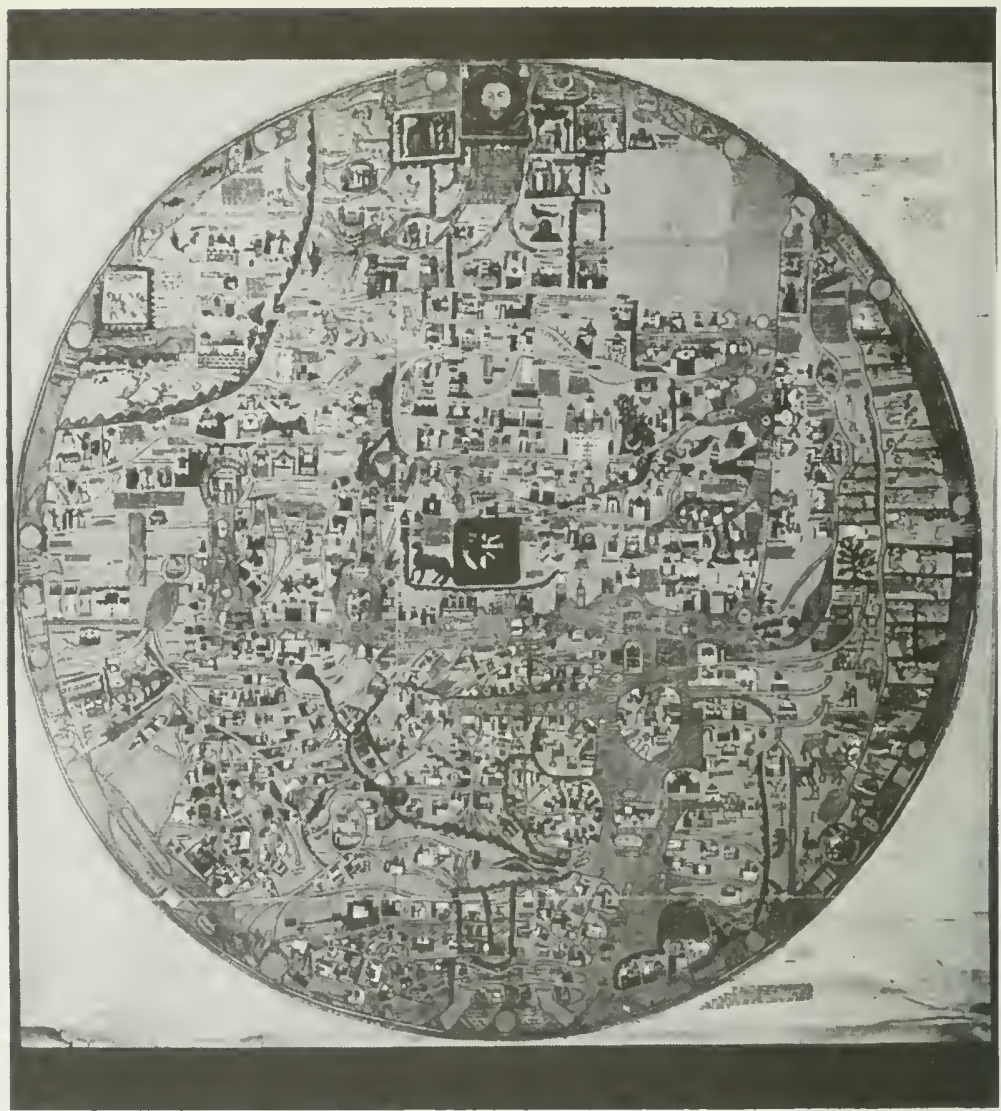

Fig. 7. World map. Ebstorf, Germany. Destroyed 1943 (ca. 1235). 


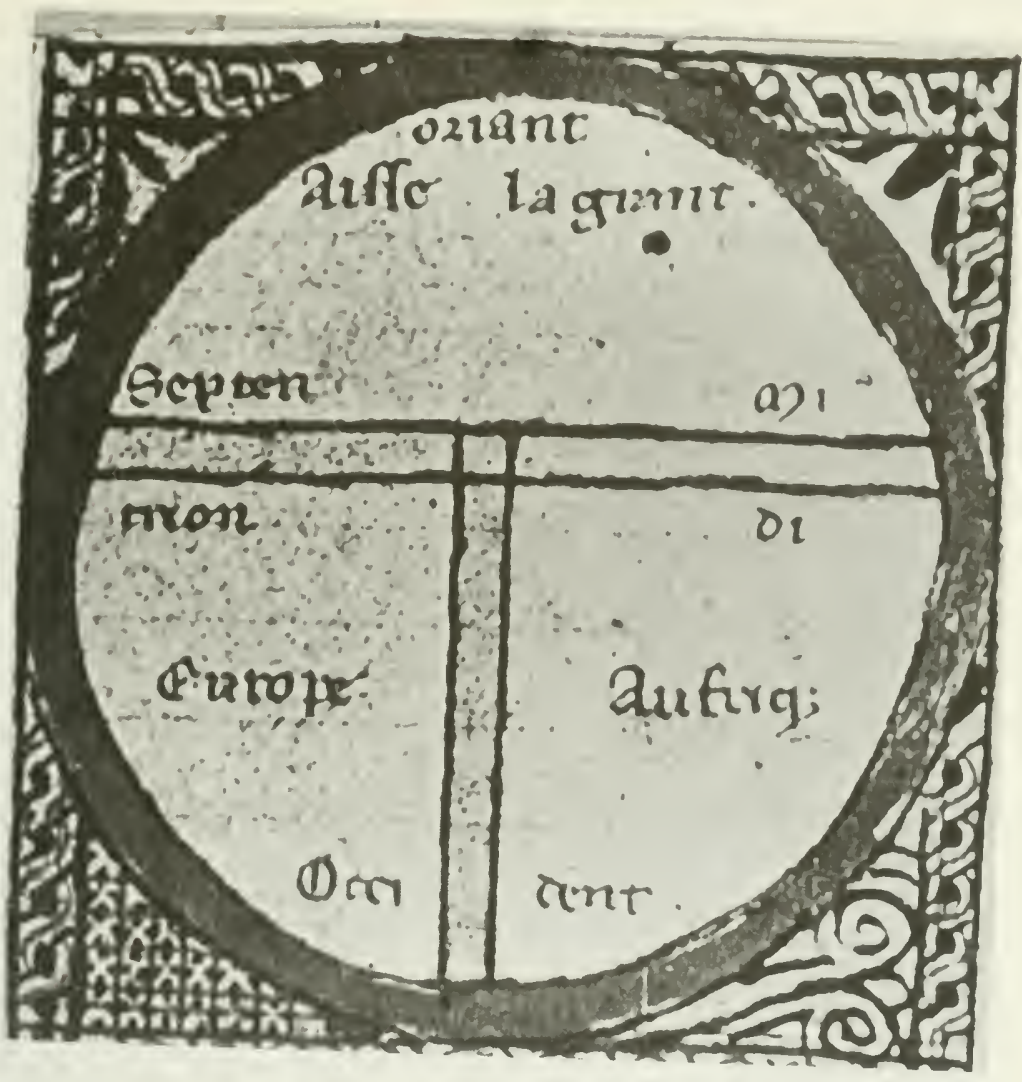

Fig. 8. T-O map in a manuscript of Brunetto Latini's Tresor. Oxford, Bodleian Library, Ms. Douce 319, f. iii of contents table (Italian, early 14 th cent.). 


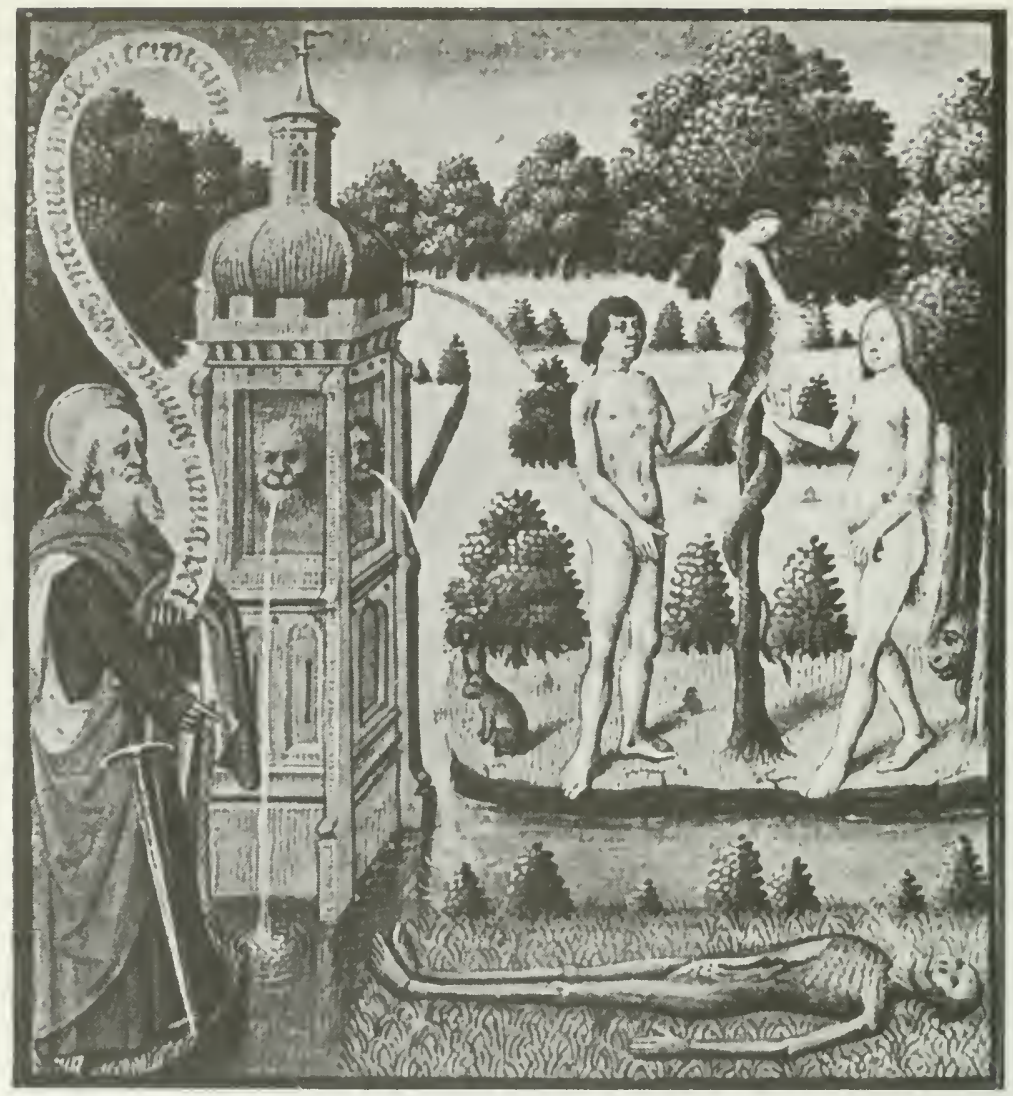

Fig. 9. God shows Death to the fallen Adam and Eve in a manuscript of St. Augustine's De civitate Dei. Paris, Bibliothèque Ste Geneviève (French, 15th cent.). 


\section{Dante, from Illumination to Television}

A remarkable illumination in an early fourteenth century manuscript of Richard de Fournival's Li Bestiaires d'amours shows Lady Memory standing before a castle with two doors, one bearing the image of an eye, the other that of an ear (figure 1). One can enter the house of Memory, Richard explains, either through the door of sight (painting) or through the door of hearing (speech):

For when one sees a story painted, whether a story of Troy or of some other thing, one sees the deeds of the brave men who were there in past times as if they were present. And so it is with speech. For when one hears a tale read, one perceives the wondrous deeds as if one were to see them taking place. And since what is past is made present by those two means, that is by painting and speech, therefore it is clear that by these two things one can come to remembrance. ${ }^{17}$

Painting and speech not only generate images in the mind, but also retrieve images already stored there.

Dante's iconography of damnation and salvation, familiar to his first audiences, has today largely been lost. Following a process similar to the one described by Richard de Fournival, the University of Toronto project attempts to reconstruct televisually this iconography, which Dante's powerful verbal imagery would trigger in the minds of his contemporaries. It does so using manuscript illuminations and various other visual images, all of which, even those from late sources, belong to Dante's and his original public's cultural patrimony and memory. Manuscript illuminations have been privileged because they are small-the Italian term for illumination is, in fact, miniatura-flat, and often ill-defined, all characteristics which make them ideally suited to television, with its small screen and relatively low definition. The TV image, and especially one thus delineated, flattens, foreshortens, and blurs distinctions, creating the impression of simultaneous presence in a manner akin to that of oral-manuscript culture. ${ }^{18}$

The primary purpose of the University of Toronto Dante video series is, therefore, to reposition the student historically in a prehumanistic setting and make him self-conscious of the process, so that the visual and oral contexts of the Comedy may be critically reexperienced. The historical repositioning I propose corresponds to the following operation. First, the student is removed from in front of 
Domenico di Michelino's famous representation of Dante (1456) in Santa Maria del Fiore (Florence). This well-known painting, which has become synonymous with Dante, shows the poet in the foreground holding his Comedy open in his hand, its pages facing the viewer. The left foreground and the background are occupied by the three realms of the afterlife; to the right is a view of Florence dominated by Brunelleschi's majestic cupola (figure 2). Once the student has been deprived of this anachronistic perspective, he is offered in its place the crowded confusion of the splendid, foreshortened representation of Florence in the "Madonna della Misericordia" fresco (1352) in the Orfanotrofio del Bigallo in Florence (figure 3). In this manner the three-dimensional "visual" space of the Renaissance is replaced by the flat, "acoustic" space of the Middle Ages (McLuhan, Gutenberg Galaxy 19), which our new electronic environment, to a great extent, recreates.

The technique used to make the programmes is straightforward: the images (mostly miniatures, as already indicated) are projected onto one or more screens, filmed, and then edited in order to create the illusion of motion and to construct a coherent narrative and commentary. The script is read by a professional narrator who does not appear on screen. Finally, original music is added. The perspective and imagery thus reclaimed are used to illustrate key aspects of Dante's poem, whether they be thematic, structural, or other.

Most of the images are necessary to recreate the context and the narrative. Some of the context-building illustrations are taken from illuminated manuscripts of the Divine Comedy. However, these manuscripts yield relatively few images, since Dante's early illustrators rarely dedicated more than one or two miniatures to each canto. Furthermore, illuminations from this source, with a few notable exceptions, seldom take us below the surface of the text (Brieger, Meiss, and Singleton in Illuminated Manuscripts). In other words, these pictures can often provide the divisione but seldom the ragionata cagione, to use Dante's own critical categories. On the other hand, there are some images, deriving from a variety of sources, which serve a precise, exegetical function, clarifying especially the "altra polisemia" of the literal narrative. I shall use the Ulysses programme, the first in the series (1985), as an example. Consider the image of the moon in Inferno 26, usually interpreted in terms of the 
poem's formal allegory, i.e. as a symbol of Reason, unilluminated by Grace. However, the traditional iconography of the goddess Luna suggests other, more allusive, interpretative possibilities which obviously have some bearing on the episode's significance. Luna was the protector of sailors and patron of folly. She was also closely associated with Fortune, and hence tragic reversal. Indeed, she is often represented as balanced on wheels, as she is in a fifteenth century illustration from the De sphaera which we used in the programme (despite its late source) because of its beauty and clarity (figure 4).

Less often, an image can illuminate the more formal, structured polysemy of Dante's text. The Cathedral Ship (figure 5), driven by Christ's passion, is almost certainly the model for the angel-propelled ship (figure 6) which transports the saved from the mouth of the Tiber to the shores of Mount Purgatory. ${ }^{19}$ Since the Cathedral Ship is in turn modelled on Noah's Ark, a clear iconographic and typological link is established between Noah's Ark, the Cathedral Ship, the celestial boat of Purgatorio 2, and Dante's ship, for that matter, metaphorically the poem itself. All four carry a similar cargo: the saved. Perhaps the most obvious image of this sort in the Ulysses programme is the thirteenth century Ebstorf mappa mundi (figure 7), in which the figure of Christ is actually superimposed on the known world, divided according to the familiar $\mathrm{T}$ and $\mathrm{O}$ pattern (figure 8 ). ${ }^{20}$ In this symbolic space, Christ's feet are placed at Gibraltar. The meaning is evident, and dramatically brings into focus the Ulysses' episode's dominant metaphor. To be saved, one must stay within the bounds. Spiritual limits are defined in geographical terms. The Pillars of Hercules stand as an imperative: do not overstep the bounds! Ulysses does: he follows the setting sun, symbol of Adam's fall, sails into darkness, and ends in shipwreck. At the tropological level, Ulysses' example warns Dante's Christian audience of the perils of spiritual transgression. ${ }^{21}$

Although much of this information could be delivered in an illustrated lecture, televisual presentation of the material adds considerably to the way meaning is produced and grasped. Words and pictures are only part of the meaning-generating strategy in these televisual commentaries. A complex series of other factors also generate meaning: these range from the angle and motion of the camera to the tone of the narrator's voice, from the graphics to the sound 
track. For example, music contributes significantly to the production of meaning. The Ulysses programme is, among other things, an account of various "sea" journeys. It starts by contrasting the circular pattern of the homeward-bound Homeric hero to the linear trajectory of Dante's Ulysses. The latter's last, doomed voyage is then compared to the successful journeys of Aeneas, the purgatorial souls, and Dante himself. Each has its music. For instance, the musical themes of the two Ulysses emphasize their differing destinies: one creates a sense of closure, the other of opening, but an opening which suggests from the outset the inevitability of shipwreck. In contrast, the celestial ship of Purgatorio 2 sails to the steady militaristic beat of a motif which recalls In exitu Israel de Aegypto.

The other televisual commentaries in the series are similarly fashioned. "Vulcan's Net: Passion and Punishment" (1987) retells the story of Paolo and Francesca, setting it against the broader theme of love and war. Its archetype is traced to the adultery of Venus and Mars, called by Ovid "the best-known story in all heaven." Finally, "Dante's Universe" (now in preparation) illustrates how Dante uses the Ptolemaic universe as a structuring device to give his poem shape and meaning. The stage upon which his Comedy unfolds is the cosmos.

\section{A Postmodern TV Dante}

The British A TV Dante's pilot on Inferno 5 is less philological than the University of Toronto programmes, and takes the opposite approach, making the past contemporary: "The good old text always is a blank for new things." So begins the Greenaway-Phillips metavideo, which deliberately sets out to bring the writerly aspects of Dante's text into the open, skilfully using it to experiment, at times parodically, with the "linguistic" conventions of the medium. The result is an entertaining, postmodern collage of televisual styles, an exercise which is not dissimilar in spirit to Dante's conscious mixing of styles or plurilinguism in the episode.

In Inferno 5 we move from the low grotesque style of the Minos sequence to a realistic description of the infernal storm to an epic catalogue of famous lovers, and finally, in the Francesca part of the episode, from the language of the dolce stil nuovo to the more realistic language of prose romance (Poggioli), all within the frame 
of chronicle. How do Greenaway and Phillips handle these shifts in style? They translate them into contemporary filmic or televisual cquivalents. They use Fellinesque imagery for Minos and the sinners, a televised weather warning about an approaching tornado in the southern USA for the bufera infernale, and the distinctive, snapshot style of British television documentaries for the epic catalogue. Then, in the Francesca segment, they play with the conventions of romance, repeating, for instance, Francesca's crucial "Lancelot" speech three times, each in a different tone.

The first part of the programme, until the whirlwind dies down and the two condemned lovers step forward, moves at feverish speed. We are bombarded by hundreds of repulsive sounds and images, held together by quick cuts. Moreover, the screen is often broken up, thus multiplying the infernal imagery and reinforcing the overwhelming sense of moral disorder and chaos. Through these and other televisual techniques, Greenaway and Phillips manage to restore to the episode's setting and contrapasso a rawness which time and commentary had largely subdued.

While today's students might be shocked by the raw and explicit imagery, they would certainly appreciate the hectic pace of the programme. Televisually literate, they regularly practise the art of "zapping" or "systematic switching" (Palmer 79), which allows them to construct a viewing experience of fragments. This video might even make them aware that Dante does something very similar with the stylistic codes of his time, which he juxtaposes and fuses with disarming ease, moving from the grotesque to the sublime and back at will. The Greenaway-Phillips video contains a number of other insights into the workings of Dante's text, which are expressed not only through the rapid accumulation of images but also through the techniques of the medium itself: the use of black and white, colour, computer graphics, odd camera angles, sound effects, and so on.

Subtitled THE LUSTFUL, the video opens with a visual word play: LUSTFUL becomes LUST and then US, a nice tropological touch. Sometimes words are so powerful that they cannot be translated into images: they must be rendered in the imagery of the words themselves. When Virgil warns Minos (vv. 22-24) not to obstruct the pilgrims' way, for their journey "is willed where will and power are one," his authorial voice speaks from the pages of a book. 
More spectacularly, the word LOVE is literally branded in fire onto the screen each time Francesca utters it in the three famous tercets (v. 100ff.) in which she attempts to justify her adultery with Paolo. Her face fills the screen while flames burn through her skull-like mouth and eye sockets. The scene is disconcerting in its interpretative accuracy: Francesca burns and dies in the fire of illicit passion. The sin becomes the punishment. This idea is brought into dramatic focus, again through the imaginative use of televisual devices in the three versions of Francesca's "Lancelot" speech (v. 121ff.) Through their poses and the colour of the light which bathes them in the first two renditions, Paolo and Francesca convey differing attitudes toward their passion, seemingly out of step with one other. Francesca's tone as she speaks the lines reveals first unconscious passion and then urgent, seductive entreaty as she seeks to embroil the viewer in her own moral downfall. In the background, the silent Paolo conveys internal struggle as Francesca delivers her lines the first time, and then anguished shame as she repeats them. In the second sequence, Francesca, like Paolo, tries to cover her nakedness with her hands. In the final rendition, both are devoid of emotion. The colour has disappeared, and Francesca delivers her lines in a flat, matter-of-fact tone. Repetition turns passion into routine, a commentary on both the nature of lust and the episode's contrapasso. The soundtrack underscores the point. From time to time in the background we hear the words "and more and more ..." The refrain, as it turns out, is part of verse 130, which Tom Phillips translates, "But more and more our eyes were forced to meet."

In the second version of the "Lancelot" speech, the lovers' attempt to cover their nakedness recalls the medieval iconography of the temptation of Adam and Eve and their expulsion from the Garden of Eden. Furthermore, Paolo is portrayed throughout as slight and vulnerable, perhaps a reference to the traditional interpretation of Adam's weakness and the Fall as male rationality capitulating to female seduction. ${ }^{22}$ The typological link between Paolo and Francesca and Adam and Eve suggested by the lovers' poses is made explicit in the final images of the programme. As Francesca pronounces the famous "Galeotto" passage- - The book was Gallehault, a gobetween"- the camera focuses on her sensuous mouth (the colour has been fully restored) which, with the pilgrim's swoon, is turned 
vertically to become a valginal image and then the $V$ of Eve. Thus the programme begins and ends with a visual play on words-a device which certainly would have pleased Dante, who, as we know, loved puns and word-play.

\section{Conclusion}

I have perhaps overstated the use and usefulness of television in teaching. If I have, it is because television is so often treated as an inferior cultural medium with inferior textual characteristics that its potential both to create "new things" and (more importantly, from our perspective) to illuminate "old things" has been underestimated. Perhaps this is due to literate culture's uneasiness with television and the new electronic orality in general, which it perceives as a threat to its values. Whatever the case, television can, I believe, be an effective teaching tool, especially if it is integrated into an overall pedagogical strategy, anchored by the more traditional teaching genres of the formal lecture and seminar. ${ }^{23}$ For Dante specifically, it can be useful in recreating an experience of the Comedy and in recovering certain messages, in particular those contained in the allusive polysemy of the literal narrative. Sometimes it can even help us penetrate the more formal hierarchical polysemy of the allegory. In the hands of sensitive directors like Greenaway and Phillips, the medium can even bring into focus the writerly aspects of the text, exposing Dante's discursive strategies and metaliterary discourse.

Bringing television and other electronic technology ${ }^{24}$ into the classroom is also an important gesture toward the present and our students' cultural formation. Even today the Divine Comedy can be enjoyed as a best seller rather than tolerated as a classic. But for this to happen, we must provide a commentary, at least initially, which does not overwhelm students but provides them with just enough information to produce meaning and pleasure. Peter Greenaway and Tom Phillips incorporate the commentary tradition into their video in a brilliant and parodic way. From time to time windows open up on the screen and an expert appears to explain some detail or other. $\mathrm{He}$ is allowed to say only what is absolutely necessary. Then his voice starts to fade; finally the window closes and he disappears. There are symbolically and ironically three such authorial figures: a Dantist, a classicist, and an ornithologist. ${ }^{25}$ 
One final anecdote to conclude. The Christmas 1988 issue of Panorama contained a full-page advertisement for a FAX machine. It proclaimed in bold print: PRENDETE UN LIBRO E TRASMETTETELO SUBITO DOVE VOLETE. The book to be sent was $L a$ Divina Commedia, complete with an image of Dante figured on one of the open pages. The ad struck my fancy for two reasons: first, that our electronic society associates Dante with the book, which continues to be an object of authority and reverence; and secondly, that this monument of words should be transmitted across telephone wires. It was with this very machine that I transmitted this paper from Rome to you in Toronto today. ${ }^{26}$

\section{University of Toronto}

\section{NOTES}

1 In addition to writing the scripts, my role is to make sure that the overall conception of each programme is realized. The programmes are produced and directed by Michael Edmunds. They are available through the Media Centre of the University of Toronto in both English and Italian versions.

2 Quoted on the cover of Petrocchi, Per conoscere Dante, which is an offshoot of the RAI television project. Petrocchi, who co-ordinated the academic side of the undertaking, is even more explicit about its objectives and intended audience in the following statement, cited by Giulia Borgese in an article in the Corriere Cultura, which appeared just a few months before the programmes were broadcast: "Speriamo in un largo pubblico, anche di esperti, anche di studenti, a cui con la massima semplicità spiegheremo il contenuto e l'importanza dei singoli canti." The book mentioned above, like the TV project on which it is based, is rather simple and straightforward in concept. It contains a biography of the poet, a brief summary of each canto, and an anthology of ten "famous" cantos with commentary. It is, however, a multimedia affair. It comes with an audiocassette with readings of the ten anthologized cantos by Albertazzi, Sbragia, and Salerno, who performed this task in the television production.

3 Phillips' translation is used, as are some of his illustrations. However, it seems that there will be a change in personnel and in look in future programmes. Greenaway, in a recent interview in La Repubblica (Porro), speaks of work on a new translation and construction of a set in preparation for the shooting of the series, which will take at least three years to complete. The programmes will not be dramatizations in the strict sense of the word, but will include actors for the major characters (as is the case for Paolo and Francesca in the 
already completed Inferno 5 segment). The English actor Bob Peck will play Dante; Sir John Gielgud is scheduled to portray Virgil.

4 On this subject, see John Ahern, "Singing the Book" and "Binding the Book," but especially the first of these two important articles, in which Ahern divides Dante's audience into four groups according to the degree of each group's "literacy" (21-22). They are 1) the idiotae or illitterati; 2) the semi-literate or indocti; 3) the volgari e non litterati (i.e. vernacular literate only); and 4) the litterati (i.e. also Latin literate). Since the second group, composed mainly of "unschooled artisans and craftsmen," could "haltingly decipher bills of sale, simple accounts and like documents," it can, for our purposes, be collapsed into the first group of pure illiterates. When it came to a complex written text like the Comedy, this group too was, in effect, illiterate: it only had access to the poem through oral recitation. Likewise, the last two groups can be merged into one, since both were capable of reading Italian. These four groups, taken together, included all social classes and related to one another in complex and paradoxical ways. The distinction that concerns me in this paper is that between the illiterate and the literate, i.e. that between those who could only receive the poem orally and those who could, if they chose, receive the poem either through a public oral performance or through a private, silent reading of it. I shall return later in this paper to the complex question of double reception on the part of the literate.

5 The term belongs to Umberto Eco who, in "Il pubblico fa male alla televisione?", argues that when there is a significant social or cultural difference between the encoder and the decoder of a text, the decoding will often be "aberrant," i.e. the message will be deciphered according to the cultural codes of the receiver rather than those of the sender. This is especially true of television, given the great social and cultural range of its audience (266). As the Letter to Cangrande (Epistle 13.10) suggests, and as Ahern argues in "Singing the Book" (32-34), Dante wrote his poem in such a way that it could be received both orally and through silent solitary reading, thus making it accessible to the widest possible audience. This, of course, does not make the Comedy immune to aberrant readings, which occur regularly and frequently. However, the women of Verona's "reading" is not of this kind: the message they draw from the poem, at both the literal and the tropological level, is encoded in the text.

6 Boccaccio's characterization of their reading competence brings to mind Eco's important distinction in The Role of the Reader between the "naive" and the "sophisticated" Model Reader. Although the women of Verona most resemble Eco's "naive" Model Reader, this category does not entirely explain their situation, since they are very competent decoders of oral communication and the messages that this mode of communication privileges. For Eco's application of his Model Reader theory to television (which is our special concern in this paper), see "L'innovazione nel seriale" (135).

7 The only characteristic of oral communication listed by them that Dante's 
poem does not possess in any measure is the "ephemeral," since the Comedy is obviously a written document, also intended to be received by a sophisticated reading public (Fiske and Hartley 124-25).

8 These are, always according to Fiske and Hartley, narrative, sequential, linear, static, artefact, abstract, permanent, individual, metonymic, logical, univocal/'consistent' (124-25).

9 Indirect confirmation comes from the reaction of the litterati of his day, like Giovanni del Virgilio (Eclogue 1.6-13) and later of the humanists, starting with Petrarch himself, who criticized Dante for writing the poem in such a way as to appeal to the "ignorant mob" (Familiares 21.15).

10 For the text of the petition, see Isidoro del Lungo 163-69. Cf. Vallone, Ahern, "Singing the Book" 33.

11 The experience, according to Boccaccio's own testimony in the four sonnets (Rime 1a Parte, 122-25) dedicated to his public reading of the poem, was not a completely satisfactory one. The form was too academic for his public, which he refers to as "questi ingrati meccanici" (123.13). Those who had criticized Boccaccio for opening up the poem to the "vulgo indegno" (123.3) had nothing to worry about. The lectura Dantis format, despite its longstanding tradition, is fundamentally antithetical to oral communication, with the paradoxical result that it has to a great extent excluded the very group which gave rise to it.

12 The women of Verona's literal "reading" must be located within the range of the Comedy's "altra polisemia," which, of course, contains a great deal more since it is the product of "la fulminante ricchezza della memoria dell'autore, in cui esperienze e letture si stratificano e accumulano, facendo sí che gli elementi vicini e assai spesso i medesimi, siano punti di numerosi reticolati e sistemi, per solito implicati e non svolti" (119). "Tal copia associativa," Contini goes on to say in one of the most penetrating pages of his Un'idea di Dante, "è fomentata da quella che culturalmente è la duplice natura di Dante, preziosa e 'comica" "(120). But commentary on the literal level of Dante's poem (not to mention the allegorical levels) "si è tradizionalmente svolto secondo la linea puntualmente erudita spettante cosí al prezioso come al 'comico'" (120). Because of this erudite focus, we may add, the aural/oral component of the allusive literal level has been left largely unexplored.

13 Just a few statistics to indicate the continuing popularity of Dante's Divine Comedy. The new Zanichelli school edition of the Comedy, prepared by Tommaso Di Salvo, sold 180,000 copies in the three year period 1985-87, and this in a highly competitive market in which the Sapegno (La Nuova Italia) and Bosco-Reggio (Le Monnier) editions held their own. Perhaps even more significant is that the new Pasquini-Quaglio edition of the poem (Garzanti), which is intended primarily not for the schools but for the general public, sold over 30,000 copies during roughly the same period (Borgese). Dante sells well abroad too, as several papers at the recent international conference on " $L$ 'opera di Dante nel mondo: edizioni e traduzioni nel Novecento," organized by the Centro Bibliografico Dantesco (Roma 27-29 aprile 1989), indicated. 
14 For second or subsequent approaches to the Comedy, whether in the context of a senior undergraduate seminar or at the graduate level, an annotated scholarly edition like Sapegno's is not only preferable but necessary. However, in this paper I am concerned rather with the student's first contact with Dante's poem, which in North America usually occurs in the junior years of university.

15 For the eye ear dichotomy, see The Gutenberg Galaxy, later applied to television in Understanding Media. See also the recently published Law's of the Media, which elaborates the distinction further. This posthumous book was reconstructed by McLuhan's son Eric. using his father's notes. For a reassessment of McLuhan's seminal work on media, see the essays in De Kerckhove and lannucci's McLuhan e la metamorfosi dell'uomo.

16 My negative assessment of the RAl production is shared by most Italian Dante scholars and television commentators. See, for example, Beniamino Placido's entertaining review in La Repubblica.

17 I use the translation of Kolve. who studies the passage and the miniature in Chaucer and the Imagery of Narrative (24-26). For the original, see Segre's critical edition of Li Bestiaires d'amours (5).

18 The manuscript culture of Dante's time, as Chaytor, McLuhan (Gutenberg Galaxy), and others have noted, was still intensely oral in nature. It was common for manuscripts to be read aloud. But more important for our purpose, the manuscript page, in contrast to print with its bold intensity and uniform precision, lacks visual definition. It has a diffuse texture and cluttered appearance, often containing text, gloss, and image simultaneously.

19 The illustration of the Cathedral Ship (figure 5) is taken from a fifteenth century Italian manuscript (New York, Pierpont Morgan Ms. M. 799, f. 234v). Therefore, this picture, too, is later than Dante's poem. However, the iconography (Kolve 297-358), of course, is much older. It was chosen because it actually represents the Ship of the Church being driven (metaphorically) by the crucified Christ who hangs on the mast. This striking image recalls Ulysses tied to the mast in the famous siren episode of the Odyssey. The correspondence led some early Christian allegorists to see Ulysses as a Christ-figure. (To Dante he was a figure more of the first than of the second Adam.) The illustration also brings into focus the cross-like posture of the angelic helmsman in Purgatorio 2 (figure 6), which none of Dante"s illuminators shows explicitly (Brieger 2: 332-35).

20 The Ebstorf map is a rather elaborate version of the $\mathrm{T}$ and $\mathrm{O}$ map (from orbis terrarum), common in Dante's time and familiar to him. Oriented with easi at the top, the "O" traces the boundary of the known world, which is concentrated entirely in the northern hemisphere. The encircling ocean covers the southern hemisphere of water. The " $T$ " inscribed in the " $O$ " divides the known world symbolically into three continents, as the example (figure 8) taken from a manuscript of Brunetto Latini's Tresor clearly shows. The creator of the enormous Ebstorf map, destroyed during World War II, was likely Gervase of Tilbury (Bagrow 48-50), an English professor of canon law 
in Bologna. The Ebstorf map probably resembles the illustration (now lost) in the manuscript of Gervase's Otia Imperialia (written in 1211).

21 For a more complete scholarly treatment of some of these ideas, see my "Ulysses' 'folle volo': The Burden of History," revised Italian version in Forma ed evento $145-88$.

22 Some of the ideas developed in the video are already suggested in Phillips' illustrations to Inferno 5 and commentary on them (288-89). One of these is precisely the Eve-Francesca typology, which has long been a commonplace in Dante criticism. However, his illustration is based on Michelangelo's representation on the ceiling of the Sistine Chapel of the temptation and expulsion of Adam and Eve from Eden, in which the traditional iconography is greatly obscured by the bold, contorted movement of Michelangelo's corpulent figures. The video Paolo and Francesca seem to have been inspired more by Northern European Renaissance painting: the various Adams and Eves of Lucas Cranach, for instance, which more faithfully preserve the medieval iconography than Michelangelo's resplendent nudes on the Sistine ceiling. Figure 9 (miniature from a fifteenth century French manuscript of St. Augustine's De civitate Dei in the Bibliothèque Ste Geneviève, Paris) provides a "typical" medieval representation. In it God shows Death to the fallen Adam and Eve.

23 I suggested such a strategy in an earlier essay published in the MLA's $A p$ proaches to Teaching Dante's Divine Comedy.

24 Such as computers, to which there seems to be less resistance. The latest edition of the new Zanichelli Divina Commedia for the schools comes equipped with a floppy disk, which contains the text of the poem plus a programme for the rapid search of single words and rhymes. However, by far the most ambitious and elaborate computer project on Dante is "The Dartmouth Dante Project" on the commentary tradition. Now in operation, it is described by Robert Hollander in this volume.

25 The Dantist is the late Kenelm Foster, O.P., of Cambridge University.

26 A much shorter version of this paper was presented (in my absence) at the international conference on "Italian Literature in North America: Pedagogical Strategies" held at York University, Toronto, Canada on March 11-12, 1989.

\section{WORKS CITED}

Ahern, John. "Binding the Book: Hermencutics and Manuscript Production in Paradiso 33." PMLA 97 (1982): 800-809.

. "Singing the Book: Orality in the Reception of Dante's Comedy." Annals of Scholarship 2 (1981): 17-40.

Alighieri, Dante. La Divina Commedia. 1955. A cura di Natalino Sapegno. 3 voll. Firenze: La Nuova Italia, 1985. 
La Divina Commedia con floppy disk. Lopera a cura di Tommaso Di Salvo. Il floppy disk a cura di Silvana Bettelli c Romolo Biolchini. Bologna: Zanichelli, 1987.

- La Commedia secondo l'anica iulgata. A cura di Giorgio Petroc-

chi. 4 voll. Milano: Mondadori, 1966-67.

Epistole. A cura di Arsenio Frugoni e Giorgio Brugnoli. In Opere

minori. Tomo 2. A cura di Pier Vincenzo Mengaldo et al. Milano-Napoli: Ricciardi, 1979.

Antonucci, Giovanni. "Televisione." Enciclopedia dantesca 5:538.

Auerbach, Eric. "Gli appelli di Dante al lettore." Studi su Dante. Milano: Feltrinelli, 1966. 292-304.

Bagrow, Leo. History of Cartography. Revised and enlarged by R.A. Skelton. London: C.A. Watts \& Co. Ltd., 1964.

Barthes, Roland. S/Z. 1970. Trans. Richard Miller. New York: Hill and Wang, 1974.

Boccaccio, Giovanni. The Life of Dante. In The Earliest Lives of Dante. Trans. James Robinson Smith. New York: Frederick Ungar, 1963.

Rime. In Opere minori in volgare. A cura di Mario Marti. Vol. 4. Milano: Rizzoli, 1972.

Borgese, Giulia. "E ora la Commedia passerà della radio alla Tv." Corriere Cultura 15 nov. 1987: 1.

Brieger, Peter, Millard Meiss, and Charles S. Singleton. Illuminated Manuscripts of the Divine Comedy. 2 vols. London: Routledge and Kegan Paul, 1969.

Chaytor, H. J. From Script to Print. 1945. London: Sidgwick and Jackson, 1966. Contini, Gianfranco. Un'idea di Dante. 1970. Torino: Einaudi, 1976.

La corrispondenza poetica di Dante Alighieri e Giovanni del Virgilio. A cura di E. Bolisani e M. Valgimigli. Firenze: Olschki, 1963.

De Kerckhove, Derrick, and Amilcare A. Iannucci, ed. McLuhan e la metamorfosi dell'uomo. Roma: Bulzoni, 1984.

Del Lungo, Isidoro. Dell'esilio di Dante. Firenze: Le Monnier, 1881.

Eco, Umberto. "L'innovazione nel seriale." 1983. Sugli specchi e altri saggi. Milano: Bompiani, 1985. 125-46.

"Il pubblico fa male alla televisione?" 1973. Dalla periferia dell'Impero. Milano: Bompiani, 1977. 261-83.

The Role of the Reader. Bloomington and London: Indiana University Press, 1979.

Fiske, John. Television Culture. London and New York: Methuen, 1987.

Fiske, John, and John Hartley. Reading Television. 1978. London and New York: Methuen, 1988.

Fournival, Richard de. Li Bestiaires d'amours di Maistre Richarl de Fornival e Li response du Bestiaire. A cura di Cesare Segre. Milano: Ricciardi, 1957.

Greenaway, Peter, and Tom Phillips, dirs. "Canto V. The Lustful." A TV Dante. Inferno. Prod. Sophie Balhetchet. Channel Four Television Lid. London. 1984. 
Havelock, Eric A. Preface to Plato. 1963. Cambridge, Mass.: Harvard University Press, 1982.

Hodge, Bob, and David Tripp. Children and Television: A Semiotic Approach. Stanford: Stanford University Press, 1986.

Hollander, Robert. "The Dartmouth Dante Project." Dante today. Special Dante issue of Quaderni d'italianistica 10.1-2 (1989): 287-98.

lannucci, Amilcare A. "Dante's Ulysses and the Homeric Tradition. Inferno 26."

Video. Prod. and dir. Michael Edmunds. University of Toronto Media Centre. Toronto, 1985.

. Forma ed evento nella Divina Commedia. Roma: Bulzoni, 1984. "Teaching Dante's Divine Comedy in Translation." Approaches to Teaching Dante's Divine Comedy. Ed. Carole Slade. New York: The Modern Language Association of America, 1982. 153-59.

"Ulysses' 'folle volo': The Burden of History." Medioevo Romanzo 3.1 (1976): 410-45.

"Vulcan's Net: Passion and Punishment. Inferno 5." Video. Prod.

and dir. Michael Edmunds. University of Toronto Media Centre. Toronto, 1987.

Kolve, V. A. Chaucer and the Imagery of Narrative. Stanford: Stanford University Press, 1984.

McLuhan, Marshall. The Gutenberg Galaxy: The Making of Typographic Man. 1962. Toronto: University of Toronto Press, 1968.

Understanding Media: The Extensions of Man. 2nd ed. New York: New American Library, 1964.

McLuhan, Marshall and Eric. Laws of the Media: The New Science. Toronto: University of Toronto Press, 1988.

Ong, Walter J. Orality and Literacy: The Technologizing of the Word. 1982. London and New York: Methuen, 1984.

Palmer, Patricia. The Lively Audience: A Study of Children around the TV Set. Sydney: Allen and Unwin, 1986.

Parodi, Marco, dir. La Divina Commedia. 100-Part Television programme. Prod. Patrizia Todaro. Academic Co-ordinator Giorgio Petrocchi. Dipartimento Scuola Educazione. RAI TV. 1988.

Petrarca, Francesco. Familiares. In Prose. A cura di G. Martellotti et al. MilanoNapoli: Ricciardi, 1955.

Petrocchi, Giorgio. Per conoscere Dante e La Divina Commedia. RAI TV. Dipartimento Scuola Educazione. Torino: Nuova ERI, 1988.

Phillips, Tom, trans. and illus. Dante's Inferno. London: Thames Hudson, 1985. Placido, Beniamino. "Galeotto fu Dante e chi lo lesse." La Repubblica 21 aprile 1988: 29.

Poggioli, Renato. "Tragedy or Romance? A Reading of the Paolo and Francesca Episode in Dante's Inferno." PMLA 72 (1957): 313-58.

Porro, Gabriele. "Pittura e tecnologia: ecco il mio tv-Dante." La Repubblica 19 ott. 1988: 29. 
Russo, Vittorio. "Appello al lettore." Enciclopedia dantesca 1: 324-26.

Schwartz, Anthony. The Responsive Chord. Garden City, N.Y.: Anchor Press, 1974.

Spitzer, Leo. "The Addresses to the Reader in the Commedia." Romanische Literatursudien 1936-1956. Tübingen: Niemcyer, 1959. 574-95. Vallone, Aldo. "Lectura Dantis." Enciclopedia dantesca 3: 606-609.

Zumthor, Paul. Introduction à la poésie orale. Paris: Éditions du Scuil, 1983. 